\title{
PENERAPAN PEMBELAJARAN KONTEKSTUAL UNTUK MENINGKATKAN KEMAMPUAN KOMUNIKASI MATEMATIS \\ DAN SIKAP SISWA SMP
}

\section{IMPLEMENTATION OF CONTEXTUAL LEARNING TO IMPROVE MATHEMATICAL COMMUNICATION ABILITY AND ATTITUDE OF JUNIOR HIGH SCHOOL STUDENTS}

\author{
Yumi Sarassanti, Sufyani Prabawanto, \& Endang Cahya \\ Universitas Pendidikan Indonesia, Indonesia \\ yumisarassanti@yahoo.co.id
}

\begin{abstract}
ABSTRAK
Penelitian ini bertujuan untuk meneliti perbedaan peningkatan kemampuan komunikasi matematis dan sikap siswa SMP. Penelitian ini merupakan penelitian kuasi eksperimen dengan desain kelompok kontrol tidak ekuivalen. Penelitian dilaksanakan pada salah satu SMP Negeri di Sambas Kalimantan Barat. Dalam penelitian ini dipilih dua kelas sebagai sampel penelitian yaitu kelas eksperimen yang pembelajarannya menggunakan pembelajaran kontekstual dan kelas kontrol yang pembelajarannya menggunakan pembelajaran konvensional. Hasil penelitian menunjukkan bahwa: 1) Peningkatan kemampuan komunikasi matematis dengan menggunakan pembelajaran kontekstual lebih baik daripada siswa yang mendapat pembelajaran konvensional; 2) Peningkatan kemampuan komunikasi matematis dengan menggunakan pembelajaran kontekstual lebih baik daripada siswa yang mendapat pembelajaran konvensional ditinjau dari kemampuan awal matematis (Tinggi, Sedang, Rendah); 3) Terdapat perbedaan peningkatan kemampuan komunikasi matematis dengan menggunakan pembelajaran kontekstual ditinjau dari kemampuan awal matematis (Tinggi, Sedang, Rendah); dan 4) Sebagian besar siswa menunjukkan respon positif terhadap pembelajaran kontekstual.
\end{abstract}

Kata Kunci: Pembelajaran Kontekstual dan Kemampuan Komunikasi Matematis.

\begin{abstract}
This study aims to examine differences in the improvement of mathematical communication skills and attitude of junior high school students. This study is a quasi-experimental study with non equivalent control group design. The research was conducted at one of the State Junior High School in Sambas, West Kalimantan. In this study, two classes were chosen as research samples, a namely experimental class whose learning uses contextual teaching and control class which learning using conventional learning. The results showed that: 1) mathematical communication ability Improved by using contextual learning better than students who received conventional learning; 2) mathematical communication skills Improved using contextual learning is better than students who received conventional learning in terms of early mathematical ability (High, Medium, Low); 3) There is a difference in the improvement of mathematical communication skills by using contextual learning in terms of early mathematical ability (High, Medium, Low); and 4) Most students show positive responses to contextual learning. Keywords: Contextual Learning and Mathematical Communication Skills.
\end{abstract}

\section{PENDAHULUAN}

Matematika merupakan ilmu universal yang mendasari perkembangan teknologi dan berperan penting dalam berbagai disiplin ilmu, di dalam kehidupan sehari-hari kita tidak terlepas dari kegiatan yang membutuhkan matematika (Kurniasih \& Dewi, 2015).

National Council of Teachers of Mathematics memaparkan lima standar proses dalam pembelajaran matematika yaitu: (1) belajar untuk memecahkan masalah (mathematical problem solving); (2) belajar untuk bernalar dan membuktikan (mathematical reasoning and proof); belajar untuk berkomunikasi (mathematical communication); (4) belajar mengaitkan ide (mathematical connection); (5) belajar untuk merepresentasikan ide-ide (mathematical 
representation) (National council of teachers of mathematics, 2000).

Sejalan dengan pendapat NCTM, Setiawan (2014) menyatakan bahwa komunikasi sangatlah penting dan diperlukan oleh sebagai sarana untuk menyampaikan pesan dari pembawa pesan ke penerima pesan. Komunikasi berfungsi sebagai media untuk membantu, menyampaikan pendapat, atau prilaku baik langsung maupun tidak langsung. Dalam berkomunikasi kita harus berpikir bagaimana caranya agar pesan yang kita sampaikan itu dapat diterima dan dipahami si penerima pesan. Kenyataan yang ditemukan di lapangan yaitu kemampuan komunikasi matematis matematis siswa masih rendah. Hal ini terjadi di penelitian Nurlia (2015) rendahnya komunikasi matematika karena siswa kurang memahami setiap materi dalam pembelajaran matematika dan karena kurangnya pemahaman konsep dasar matematika pada siswa dan kurang aktifnya siswa dalam proses pembelajaran matematika.

Banyak cara yang dapat dilakukan untuk meningkatkan kemampuan komunikasi matematis siswa. Salah satu alternatif yang dapat dilakukan adalah dengan penerapan pembelajaran kontekstual. Menurut Sugandi, A (2014) alasan mengapa memilih pembelajaran kontekstual diantaranya dengan menyajikan masalah kontesktual pada awal pembelajaran merupakan salah satu stimulus dan pemicu siswa untuk berpikir. Alasan lain melalui pembelajaran kontesktual, siswa juga belajar untuk bertanggung jawab dalam kegiatan belajar, tidak sekedar menjadi penerima informasi yang pasif, namun harus aktif mencari informasi yang diperlukan sesuai dengan kapasitas yang dimiliki.

Menurut Nurhadi dalam Rusman (2010:189) Pembelajaran Kontekstual merupakan konsep belajar yang dapat membantu guru mengaitkan antara materi yang diajarkannya dengan situasi dunia nyata siswa dan mendorong siswa membuat hubungan antara pengetahuan yang dimilikinya dengan penerapannya dalam kehidupan mereka, sebagai anggota keluarga dan masyarakat. Pembelajaran kontekstual menurut Komalasari (2011), pembelajaran kontekstual adalah pendekatan pembelajaran yang mengaitkan antara materi yang dipelajari dengan kehidupan nyata siswa sehari-hari, baik dalam lingkungan keluarga, sekolah, masyarakat maupun warga negara, dengan tujuan untuk menemukan makna materi tersebut bagi kehidupannya. Menurut (Trianto, 2010), pembelajaran kontekstual merupakan suatu konsepsi yang membantu guru mengaitkan konten mata pelajaran dengan situasi dunia nyata, dan memotivasi siswa membuat hubungan antara pengetahuan dan penerapannya dalam kehidupan mereka sebagai anggota keluarga, warga negara, dan tenaga kerja.

Menurut beberapa pendapat para ahli di atas dapat disimpulkan bahwa pembelajaran kontekstual adalah suatu konsep belajar yang dapat merangsang otak anak untuk menyusun pola-pola yang mewujudkan makna sehingga jika anak diberi suatu materi pelajaran, mereka dapat menghubungkan antara pengetahuan yang mereka miliki dengan penerapannya dalam kehidupan seharihari, dengan melibatkan 7 komponen utama pembelajaran efektif, yaitu: konstruktivisme (constructivism), menemukan (Inquiry), 
bertanya (Questioning), masyarakat belajar (Learning Community), pemodelan (Modeling), refleksi (Reflection), dan penilaian sebenarnya (Authentic Assessment).

Salah satu upaya dalam mengembangkan kemampuan komunikasi matematis siswa adalah dengan mencari penyebab yang diperkirakan dapat memberikan pengaruh positif terhadap peningkatan kemampuan komunikasi matematis dan berpikir kreatif. Penyebab yang dimaksud adalah pendekatan pembelajaran yang diterapkan oleh guru dan faktor kemampuan awal matematika siswa. Terdapat beberapa hasil penelitian yang kemampuan awal matematis (KAM) masih rendah dengan rata-rata dibawah 4,00 menurut beberapa penelitian yang dilakukan oleh (Sulastri, 2012). Hal ini menunjukkan perlu adanya usaha untuk meningkatkan kemampuan komunikasi siswa dengan melihat kemampuan awal matematika siswa serta bertujuan untuk melihat apakah pembelajaran kontekstual merata pada setiap kategori KAM atau hanya pada kategori KAM tertentu saja. Apabila merata pada setiap kategori KAM maka dapat dikatakan bahwa penerapan pembelajaran kontekstual cocok diterapkan pada semua kategori yaitu tinggi, sedang, dan rendah.

Penelitian ini bertujuan untuk mengetahui: 1) Peningkatan kemampuan komunikasi matematis dengan menggunakan pembelajaran kontekstual lebih baik daripada siswa yang mendapat pembelajaran konvensional 2) Peningkatan kemampuan komunikasi matematis dengan menggunakan pembelajaran kontekstual lebih baik daripada siswa yang mendapat pembelajaran konvensional ditinjau dari kemampuan awal matematis (Tinggi, Sedang, Rendah) 3) Terdapat perbedaan peningkatan kemampuan komunikasi matematis dengan menggunakan pembelajaran kontekstual ditinjau dari kemampuan awal matematis (Tinggi, Sedang, Rendah).

\section{METODE PENELITIAN}

Bentuk penelitian yang digunakan dalam penelitian ini adalah quasi eksperimental dengan rancangan nonequivalen control group design. Bentuk quasi eksperimental digunakan dalam penelitian ini karena tidak semua variabel yang terkait dengan penelitian dapat dikontrol oleh peneliti.

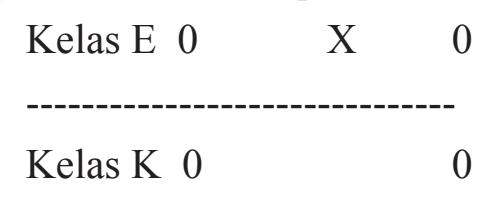

Keterangan :

$0=$ Test yang diberikan kemampuan siswa pretes dan postes

$\mathrm{X}=$ Pembelajaran yang menggunakan pembelajaran kontekstual

--- = Subjek tidak dikelompokkan secara acak

Instrumen yang digunakan dalam penelitian ini adalah tes kemampuan komunikasi matematis. Teknik analisis data yang digunakan untuk uji hipotesis adalah uji t satu sampel. Untuk mengetahui peningkatan kemampuan komunikasi dan berpikir kreatif matematis siswa digunakan rumus normalized gain. Sedangkan untuk mengetahui perbedaan peningkatan kemampuan matematis siswa digunakan uji anova satu jalur. 


\section{HASIL DAN PEMBAHASAN}

Tabel 1

Deskriptif Uji Statistik

\begin{tabular}{cccc}
\hline & Uji Statistik & Hasil & Keterangan \\
\hline Hipotesis 1 & Mann-Whitney & 0,005 & Tolak $\mathrm{H}_{0}$ \\
\hline Hipotesis 2.a KAM Tinggi & Mann-Whitney & 0,001 & Tolak $\mathrm{H}_{0}$ \\
\hline Hipotesis 2.b KAM Sedang & $\mathrm{t}$ & 0,053 & Terima $\mathrm{H}_{0}$ \\
\hline Hipotesis 2.c KAM Rendah & $\mathrm{t}$ & 0,465 & Terima $\mathrm{H}_{0}$ \\
\hline Hipotesis 3 & Kruskal-Willis & 0,001 & Tolak $\mathrm{H}_{0}$ \\
\hline Hipotesis 3.a KAM Tinggi vs Sedang & Mann-Whitney & 0,001 & Tolak $\mathrm{H}_{0}$ \\
\hline Hipotesis 3.b KAM Tinggi vs Rendah & Mann-Whitney & 0,003 & Tolak $\mathrm{H}_{0}$ \\
\hline Hipotesis 3.c KAM Sedang vs Rendah & Mann-Whitney & 0,199 & Terima $\mathrm{H}_{0}$ \\
\hline
\end{tabular}

Berdasarkan tabel 1, hipotesis 1 menunjukkan bahwa nilai sig.(1-tailed) $<\alpha$ dengan demikian $\mathrm{H}_{0}$ di tolak artinya peningkatan kemampuan komunikasi matematis siswa yang pembelajarannya menggunakan kontesktual lebih baik dengan siswa yang pembelajarannya menggunakan pembelajaran konvensional. Hipotesis 2.a menunjukkan bahwa nilai sig.(1-tailed) $<\alpha$ dengan demikian $\mathrm{H}_{0}$ di tolak artinya peningkatan kemampuan komunikasi matematis siswa berkemampuan tinggi yang pembelajarannya menggunakan pembelajaran kontesktual lebih baik dengan siswa yang pembelajarannya menggunakan pembelajaran konvensional. Hipotesis 2.b menunjukkan bahwa nilai sig.(1-tailed) $>\alpha$ dengan demikian $\mathrm{H}_{0}$ di terima artinya peningkatan kemampuan komunikasi matematis siswa berkemampuan sedang yang pembelajarannya menggunakan pembelajaran kontesktual tidak lebih baik dengan siswa yang pembelajarannya menggunakan pembelajaran konvensional. Hipotesis 2.c menunjukkan bahwa nilai sig.(1-tailed) $>\alpha$ dengan demikian $\mathrm{H}_{0}$ di terima artinya peningkatan kemampuan komunikasi matematis siswa berkemampuan rendah yang pembelajarannya menggunakan pembelajaran kontesktual tidak lebih baik dengan siswa yang pembelajarannya menggunakan pembelajaran konvensional.

Berdasarkan Hipotesis 3 diperoleh nilai sig $<\alpha$ sehingga $\mathrm{H}_{0}$ ditolak. Dengan demikian, terdapat perbedaan peningkatan kemampuan komunikasi matematis siswa yang memproleh pembelajaran kontekstual ditinjau dari kemampuan awal matematis siswa (Tinggi, Sedang, Rendah). Hipotesis 3.a Hal ini diperoleh berdasarkan nilai signifikan yaitu 0,001 yang mengakibatkan $\mathrm{H}_{0}$ ditolak, artinya terdapat perbedaan peningkatan kemampuan komunikasi antara siswa berkemampuan tinggi dengan siswa berkemampuan sedang pada kelas kontekstual. Hipotesis 3.b Hal ini diperoleh berdasarkan nilai signifikan yaitu 0,003 yang mengakibatkan $\mathrm{H}_{0}$ ditolak, artinya terdapat perbedaan peningkatan kemampuan komunikasi antara siswa berkemampuan tinggi dengan siswa berkemampuan rendah pada kelas kontekstual. Hipotesis 3.c Hal ini diperoleh berdasarkan nilai signifikan yaitu 0,199 yang mengakibatkan $\mathrm{H}_{0}$ diterima, artinya tidak terdapat perbedaan peningkatan kemampuan komunikasi antara siswa berkemampuan sedang dengan siswa berkemampuan rendah pada kelas kontekstual. Dengan demikian, antara ketiga KAM(Tinggi, Sedang, Rendah) pembelajaran kontekstual memberikan peningkatan yang relatif sama pada KAM sedang dan rendah. 
Berdasarkan hasil jawaban siswa terhadap angket sikap siswa, secara umum siswa menunjukkan sikap positif terhadap pelajaran matematika, pembelajaran dengan pendekatan kontekstual dan soal-soal kemampuan komunikasi dan berpikir kreatif yang diberikan selama proses pembelajaran. Hasil persentase yang diperoleh dari seluruh pernyataaan yang terdiri dari pernyataan positif dan pernyataan negatif diperoleh rata-rata untuk pernyataan positif $87,1 \%$ sedangkan untuk pernyataan negative $85,3 \%$ dapat ditarik kesimpulan bahwa pembelajaran kontekstual memperoleh respon yang baik dari siswa.

\section{SIMPULAN}

Penelitian ini terkait materi bangun ruang sisi datar pada siswa kelas VIII di SMP Negeri 1 Pemangkat. Berdasarkan hasil analisis data dan pembahasan hasil penelitian, maka dapat diambil kesimpulan sebagai berikut:

1. Peningkatan kemampuan komunikasi matematis siswa yang pembelajarannya menggunakan pembelajaran kontekstual lebih baik daripada siswa yang pembelajarannya menggunakan pembelajaran konvensional.

2. Peningkatan kemampuan komunikasi matematis siswa berkemampuan tinggi yang pembelajarannya menggunakan pembelajaran kontesktual lebih baik dengan siswa yang pembelajarannya menggunakan pembelajaran konvensional. Sedangkan peningkatan kemampuan komunikasi matematis siswa berkemampuan sedang yang pembelajarannya menggunakan pembelajaran kontesktual tidak lebih baik dengan siswa yang pembelajarannya menggunakan pembelajaran konvensional. Sedangkan peningkatan kemampuan komunikasi matematis siswa berkemampuan rendah yang pembelajarannya menggunakan pembelajaran kontesktual tidak lebih baik dengan siswa yang pembelajarannya menggunakan pembelajaran konvensional.

3. Terdapat perbedaan peningkatan kemampuan komunikasi matematis yang signifikan antara siswa berkemampuan tinggi dengan siswa yang berkemampuan sedang di kelas kontekstual; 2) terdapat perbedaan peningkatan kemampuan komunikasi matematis yang signifikan antara siswa berkemampuan tinggi dengan siswa yang berkemampuan rendah di kelas kontekstual; 3) tidak terdapat perbedaan peningkatan kemampuan komunikasi matematis antara siswa berkemampuan sedang dengan siswa berkemampuan rendah pada kelas kontekstual.

4. Sebagai besar siswa menunjukkan respon positif terhadap pembelajaran kontekstual.

\section{DAFTAR RUJUKAN}

Komalasari, K. (2011). Pembelajaran kontekstual: konsep dan aplikasi. Bandung: Refika Aditama.

Kurniasih, N., \& Dewi, A. K. (2015). Penerapan Model Connected Mathematic Project (CMP) Berbantu Media Puzzle Pada Peningkatan Kemampuan Penalaran Dan Komunikasi Matematis Siswa Kelas VII A SMP Negeri 3 GOMBONG Tahun Pelajaran 2014/2015. Prosiding Seminar Nasional Matematika Dan Pendidikan Matematika, 1(1), 65-78.

National council of teachers of mathematics. (2000). Principles and Standards for School Mathematics. Reston, Virginia: NCTM lnc. R

Nurlia. (2015). Kemampuan Komunikasi Matematika Dalam Pembelajaran Matematika Sebelum Dan Setelah Penerapan Pendekatan Matematika Realistik. Jurnal Daya Matematis, , 3(3), 44-54. 
Rusman. (2010). Model-Model Pembelajaran: Mengembangkan Profesionalisme Guru (2nd ed.). Jakarta: Rajawali Pers.

Setiawan, W. (2014). Penerapan Pendekatan Kontekstual Untuk Meningkatkan Kemampuan Komunikasi Dan Pemecahan Masalah Matematik. Prosiding Seminar Nasional Pendidikan, 2(1), 55-76.

Sugandi, A, K. (2014). Pengaruh Pendekatan Kontekstual Terhadap Kemampuan Berpikir Matematis Tingkat Tinggi Siswa SMP. Prosiding Seminar Nasional Pendidikan Volume 2., 2(3), 44-56.

Sulastri. (2012). Meningkatkan Kemampuan Pemecahan Masalah Dan Komunikasi Matematis Siswa Sekolah Menengah Pertama Dengan Pembelajaran Kooperatif Tipe Jigsaw. Universitas Pendidikan Indonesia.

Trianto. (2010). Model Pembelajaran Terpadu. Jakarta: Bumi Aksara. 